\title{
AN EXTENSION OF ORDER PRESERVING OPERATOR INEQUALITY
}

\author{
TAKAYUKI FURUTA
}

Abstract. We discuss an order preserving operator inequality and also we transform it into log majorization.

Mathematics subject classification (2010): 47A63.

Keywords and phrases: Löwner-Heinz inequality, order preserving operator inequality, log majorization.

\section{REFERENCES}

[1] T. ANDO AND F. HiAI, Log majorization and complementary Golden-Thompson type inequalities, Linear Alg. and Its Appl., 197, 198 (1994), 113-131.

[2] R. Bhatia, Positive Definite Matrices, Princeton Univ. Press, 2007.

[3] M. FuJI, Furuta's inequality and its mean theoretic approach, J. Operator Theory, 23 (1990), 67-72.

[4] M. FUJII AND E. KAMEI, Mean theoretic approach to the grand Furuta inequality, Proc. Amer. Math. Soc., 124 (1996), 2751-2756.

[5] M. Fuji, A. MATSUMOTO AND R. NAKAmoto, A short proof of the best possibility for the grand Furuta inequality, J. of Inequal. and Appl., 4 (1999), 339-344.

[6] T. FurutA, $A \geqslant B \geqslant 0$ assures $\left(B^{r} A^{p} B^{r}\right)^{1 / q} \geqslant B^{(p+2 r) / q}$ for $r \geqslant 0, p \geqslant 0, q \geqslant 1$ with $(1+2 r) q \geqslant p+2 r$, Proc. Amer. Math. Soc., 101 (1987), 85-88.

[7] T. FURUTA, Elementary proof of an order preserving inequality, Proc. Japan Acad., 65 (1989), 126.

[8] T. FuRUTA, An extension of the Furuta inequality and Ando-Hiai log majorization, Linear Alg. and Its Appl., 219 (1995), 139-155.

[9] T. FURUTA, Simplified proof of an order preserving operator inequality, Proc, Japan Acad., 74 (1998), 114.

[10] T. FURUTA, Invitation to Linear Operators, Taylor \& and Francis, 2001, London.

[11] T. FURUTA AND D. WANG, A decreasing operator function associated with the Furuta inequality, Proc. Amer. Math. Soc., 126 (1998), 2427-2432.

[12] T. Furuta, M. YANAGIDA AND T. YAMAZAKI, Operator functions implying Furuta inequality, Math. Inequal. Appl., 1 (1998), 123-130.

[13] E. HeInZ, Beiträge zur Störungsteorie der Spektralzerlegung, Math. Ann., 123 (1951), $415-438$.

[14] E. KAMEI, A sattelite to Furuta's inequality, Math. Japon., 33 (1988), 883-886.

[15] E. KAMEI, Parametrized grand Furuta inequality, Math. Japon., 50 (1999), 79-83.

[16] F. Kubo And T. Ando, Means of positive linear operators, Math. Ann., 246 (1980), 205-224.

[17] K. LöWNER, Über monotone MatrixFunktionen, Math. Z., 38 (1934), 177-216.

[18] G. K. Pedersen, Some operator monotone functions, Proc. Amer. Math. Soc., 36 (1972), 309-310.

[19] K. TANAHASHI, Best possibility of the Furuta inequality, Proc. Amer. Math. Soc., 124 (1996), 141-146.

[20] K. TANAHASHI, The best possibility of the grand Furuta inequality, Proc. Amer. Math. Soc., 128 (2000), 511-519.

[21] T. YAMAZAKI, Simplified proof of Tanahashi's result on the best possibility of generalized Furuta inequality, Math. Inequal. Appl., 2 (1999), 473-477. 